\title{
DENDROFLORA PARKA IVANA MAŽURANIĆA U NOVOM VINODOLSKOM
}

\section{WOODY SPECIES IN THE PARK IVAN MAŽURANIĆ IN NOVI VINODOLSKI}

\section{Poje, D. Jemrić, Dubravka Dujmović Purgar, Ines Han Dovedan}

\section{SAŽETAK}

Grad Novi Vinodolski smješten je na jugoistočnom dijelu Primorskogoranske županije. Sa sjeverozapadne strane naslanja se na Kvarnerski zaljev, sa sjevera na Gorski kotar i obronke gorskog masiva Kapele, a s jugoistočne na obronke Velebita. Park Ivana Mažuranića, kao jedna od najvećih uređenih zelenih površina, ima važnu prostornu, kulturnu, povijesnu i gospodarsku ulogu za Novi Vinodolski. Kako bi park kvalitetno ispunjavao svoje funkcije i na pozitivan način upotpunjavao turističku ponudu, neophodno je da bude redovito i stručno održavan. Da bi se ostvario taj cilj potrebna je, između ostalog, sveobuhvatna analiza njegova biljnog materijala. Cilj rada bio je utvrditi i analizirati postojeću dendrofloru parka. Terensko istraživanje provedeno je 2014. i 2016. godine tijekom vegetacijskih sezona. Rezultati ukazuju na veliku raznolikost drvenastih biljnih vrsta kojih je zabilježeno 67 iz ukupno 32 porodice. Najzastupljenije porodice su Oleaceae (7 vrsta; 21,87\%), Fabaceae (6 vrsta; 18,75\%), Pinaceae (6 vrsta; 18,75\%) i Rosaceae (5 vrsta; $15,62 \%)$ dok je čak $51,12 \%$ porodica zastupljeno samo s jednom vrstom. Fitogeografskom analizom utvrđeno je da najviše vrsta pripada adventivnim vrstama $(35,82 \%)$ i mediteranskom flornom elementu (26,87\%). Istraživanje pokazuje kako je većina dendroflore parka prilagođena uvjetima lokacije što bitno pridonosi ekonomičnosti održavanja.

Ključne riječi: Novi Vinodolski, javni park, analiza, biljni materijal, dendroflora 
M. Poje i sur.: Dendoflora parka Ivana Mažuranića u Novom Vinodolskom

\begin{abstract}
The town of Novi Vinodolski is located in the south-eastern part of the Primorje-Gorski Kotar County. It lies on the northwest side of the Kvarner bay, with Gorski Kotar and the slopes of the mountain massif of Kapela in the north, and the slopes of Velebit in the south-east. Park Ivan Mažuranić, as one of the largest landscaped green area, has an important spatial, cultural, historical and economic role for Novi Vinodolski. In order to fulfil its functions and to complement the tourist offer in a positive way, the park must be regularly and professionally maintained. To achieve this goal it is necessary, among other things, to comprehensively analyze its plant material. The aim of the research was to establish and analyze the existing park dendroflora. Field research was conducted during vegetation seasons of 2014 and 2016. The results show a great variety of woody plant species, of which 67 out of 32 families were recorded. The most frequent families are Oleaceae (7 species; 21.87\%), Fabaceae (6 species; 18.75\%), Pinaceae (6 species; 18.75\%) and Rosaceae (5 species; $15.62 \%$ ), while $51.12 \%$ of families are represented only by one species. Phytogeographic analysis shows that most species belong to the adventive species (35.82\%) and mediterranean floral element (26.87\%). Research suggests that most of the dendroflora of the park are adapted to the location conditions which significantly contributes to maintenance economics.
\end{abstract}

Key words: Novi Vinodolski, public park, analysis, plant material, woody species

\title{
UVOD I CILJ ISTRAŽIVANJA
}

Grad Novi Vinodolski smješten je na jugoistočnom dijelu Primorskogoranske županije ispod blago spuštenih obronaka šumovite Kapele, pokraj plodne Vinodolske doline, uz razvedenu obalu Podvelebitskog odnosno Vinodolskog kanala. Površina grada iznosi $265,08 \mathrm{~km}^{2}$ što ga čini četvrtom jedinicom lokalne samouprave u Županiji. Administrativno područje Grada obuhvaća dvadeset naselja (Izvješće o stanju u prostoru Grada Novi Vinodolski za razdoblje od 2007. do 2014. godine, 2014.). Novljanska rivijera proteže se na $17,5 \mathrm{~km}$ zračne linije. Obalni pojas je krševit i djelomično pokriven mediteranskim raslinjem (Strategija razvoja Grada Novog Vinodolskog za razdoblje od 2015. do 2020. godine, 2015.). 
Park Ivana Mažuranića ima veliku prostornu, kulturnu, povijesnu i gospodarsku važnost za Novi Vinodolski. Prema Urbanističkom planu uređenja naselja Novi Vinodolski (2017.), kategoriziran je kao javni gradski park (Z1). Nalazi se u južnom dijelu Novog Vinodolskog i proteže se u smjeru sjeverozapad - jugoistok od prilaza kod ugostiteljskog objekta Vrtić do prilaza Lopara te od šetnice dr. Franje Tuđmana do ulice Lukavice.

Park je smješten u obalnom području (Slika 1) koje prema Köppenovoj klasifikaciji klime pripada Cfa klimatskoj zoni (Šegota i Filipčić, 2003.). To je umjereno topla vlažna klima s vrućim ljetom (srednja mjesečna temperatura iznad $22{ }^{\circ} \mathrm{C}$ ). Prosječna temperatura zraka u zimskim mjesecima kreće se oko $10^{\circ} \mathrm{C}$, dok u ljetnim mjesecima ne prelazi 27 do $29^{\circ} \mathrm{C}$. Tako je srednja godišnja temperatura $13,1{ }^{\circ} \mathrm{C}$, između izoterma 14 i $10{ }^{\circ} \mathrm{C}$. Srednja godišnja količina padalina je od $1.250 \mathrm{~mm}$ do $2.000 \mathrm{~mm}$ (Izvješće o stanju u prostoru Grada Novi Vinodolski za razdoblje od 2007. do 2014. godine, 2014.).

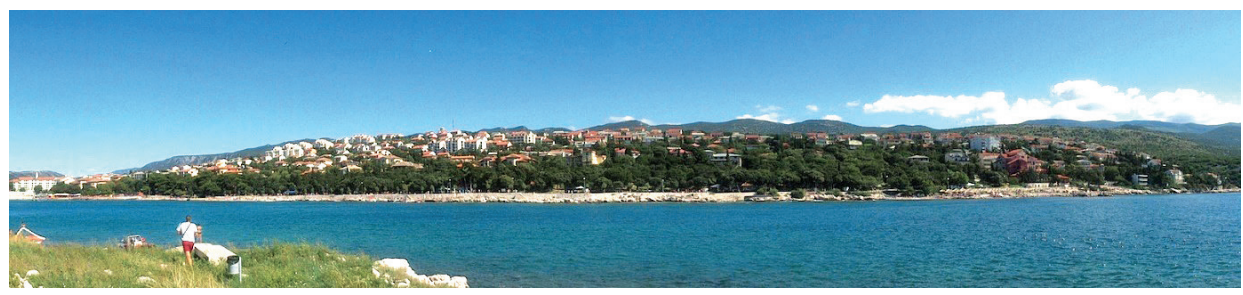

Slika 1. Panoramski pogled na park s otoka San Marino (Izvor: Nives Antić, 2014.)

Figure 1 Panoramic view of the park from the island of San Marino (Source: Nives Antić, 2014.)

Ukupna površina parka iznosi $17.734 \mathrm{~m}^{2}$ od čega zelene površine zauzimaju $11.764 \mathrm{~m}^{2}$, pošljunčane staze $3960 \mathrm{~m}^{2}$, a popločene $2010 \mathrm{~m}^{2}$ (Jemrić, 2018.). Zbog smještaja uz glavnu gradsku plažu, park je jedna od najčešće korištenih uređenih zelenih površina u Novom Vinodolskom budući da se dnevno stotine kupača zadržava unutar njegovih granica gdje nalaze hlad tijekom vrućih ljetnih mjeseci. S druge strane, takav način korištenja parka značajno povećava sredstva potrebna za njegovo održavanje.

U Novom Vinodolskom turizam službeno započinje izgradnjom prvih kupališta 1878. godine (Blažević, 2014.). Već početkom 20. stoljeća primjećuje se porast broja posjetitelja tijekom ljetnih mjeseci pa se 1902. godine osniva 
Društvo za uređenje i poljepšanje Novoga i okolice (Seferagić, 2010.). Na njihovu inicijativu, godinu dana kasnije, počinje prikupljanje donacija za formiranje i uređivanje parka. Grupa bogatijih građana otkupila je zemljište uz neposrednu blizinu mora od privatnih vlasnika i poklonila ga općini (Kabalin, 1985.). U to vrijeme tamo je uglavnom bio primorski krš pošumljen sadnicama crnog bora. Donacijama građana formirane su prve plohe parka, zasađena su i druga crnogorična i bjelogorična stabla te razno mediteransko bilje koje se moglo prilagoditi uvjetima lokacije (Ježić, 1963.). Uz južnu granicu parka, 1905. godine počinje gradnja obalnog puta do ruševina kasnoantičke utvrde Lopar (Kabalin, 1995.). U Vodiču koji je 1912. godine izdao Lječilišni odbor Novog Vinodolskog, spominje se park, ali bez navođenja naziva (Kabalin, 1985.). Godine 1923. dovršeno je uređenje novljanskog parka od Lišnja do Lopara (Babić, 1995.). Zanimljivo je spomenuti kako se na jednoj razglednici iz 1931. godine park i šetnica nazivaju Perivojem kraljevića Tomislava dok Brozović (1938.) naziva park kupališnim: ... cijeli teren uz more, gdje se danas diže kupališni park, bio [je] jedna krševita pustinja. Tijekom Drugog svjetskog rata, parkovi i ostale gradske zelene površine bili su ispresijecani vojničkim rovovima (Kabalin, 1995.). Neposredno nakon rata, prilikom pošumljavanja okolice Novog, praznine u parku nadopunjene su odraslim sadnicama crnog bora iz šume kod Bribira, nasadima ukrasnog drveća, sezonskog cvijeća i trajnica te je upotpunjena postojeća mreža staza uz koje je posađen ružmarin. Uz postavljeno prirodno kamenje posađeno je različito mediteransko bilje. Veća zastupljenost nasada ružmarina, o čemu svjedoče brojne fotografije, dala je povod jednom posjetitelju da napiše članak u jednom zagrebačkom dnevniku o Novom Vinodolskom kao „gradu ružmarina“ (Ježić, 1963.). U parku je 21. kolovoza 1955. godine svečano otkrivena bista Ivana Mažuranića, rad akademskog kipara Vinka Matkovića. U programu priprema za turističku sezonu iz 1984. godine navodi se akcija sadnje novih sadnica u parku kraj kupališta (Kabalin, 1985.). Nekoliko godina kasnije, šetalište uz park naziva se imenom Ivana Mažuranića, a sam park - Lukavice. U razdoblju od 2002. do 2004. godine obnovljeni su kameni rubnjaci na stazama. Godine 2008. gradsko komunalno trgovačko društvo Ivanj d.o.o. navodi kako su na parceli oko spomenika Ivanu Mažuraniću posađene sljedeće biljne vrste: Magnolia grandiflora L. (krupnocvjetna magnolija), Taxus baccata L. (tisa), Myrtus communis L. (mirta), Nandina domestica Thunb. (nandina), Ruscus hypoglossum L. (mekolisna veprina), Chamaerops excelsa Thunb. (visoka 
žumara), Chamaerops humilis L. (niska žumara), Cistus salviaefolium L. (bušin), Rosmarinus officinalis L. 'Corsica' (puzajući ružmarin) te ostale vrste koje služe kao pokrivači tla ili ispuna između viših, dominantnijih vrsta. Oko samog spomenika napravljen je topijarij od ružmarina u obliku glagoljičnog slova V. Sve navedeno izvedeno je prema projektu Studija Perivoj d.o.o. iz 2005. godine koji je obuhvaćao cijeli park. Prema tom projektu, predviđena je i izgradnja dvaju dječjih igrališta, fontana, klupe u obliku različitih slova uglate glagoljice, rasvjeta i automatsko navodnjavanje, ali to do danas nije realizirano. Nakon 2008., u parku nisu vršeni nikakvi veći zahvati obnove. Nakon više od stotinu godina, park službeni naziv konačno dobiva 2015. godine kada je Gradsko vijeće jednoglasno usvojilo Odluku o određivanju imena šetnice, ulice, parka na području Grada Novog Vinodolskog, prema kojoj se neimenovanom parku određuje ime „Park Ivana Mažuranića“ (Odluka o određivanju imena šetnice, ulice i parka na području Grada Novog Vinodolskog, 2015.).

Jedan od osnovnih koraka pri izradi plana održavanja parkova je inventarizacija kompletnog biljnog fonda (McBride i Nowak, 1989.). Većina istraživanja u najvećoj mjeri fokusirana je na drvenaste biljne vrste, a osobito na drveće. S obzirom na tehničku pomoć koja se koristi u samom postupku, postoje četiri osnovne metode za inventarizaciju drveća: metoda sa satelitskom podrškom, metoda s avionskom podrškom, metoda skeniranja terena uz pomoć fotografija i terensko istraživanje (Nielsen i sur., 2014.). Od navedenih metoda, za prikupljanje podataka najčešće se koristi terensko istraživanje iako je radno intenzivno i obično zahtjeva puno vremena (radnih sati). Ono obuhvaća izravan, neposredan pregled postojećeg biljnog fonda od stručnjaka (Adkins i sur., 1997.; Martin i sur., 2011.).

Ciljevi istraživanja bili su analizirati dendrofloru parka i utvrditi taksonomsku pripadnost te životne oblike i florne elemente zabilježenih vrsta. 
M. Poje i sur.: Dendoflora parka Ivana Mažuranića u Novom Vinodolskom

\section{MATERIJALI I METODE}

Terensko istraživanje provedeno je u parku Ivana Mažuranića u Novom Vinodolskom tijekom vegetacijskih sezona 2014. i 2016. godine. Istraživanjem je obuhvaćen cijeli park (Slika 2).

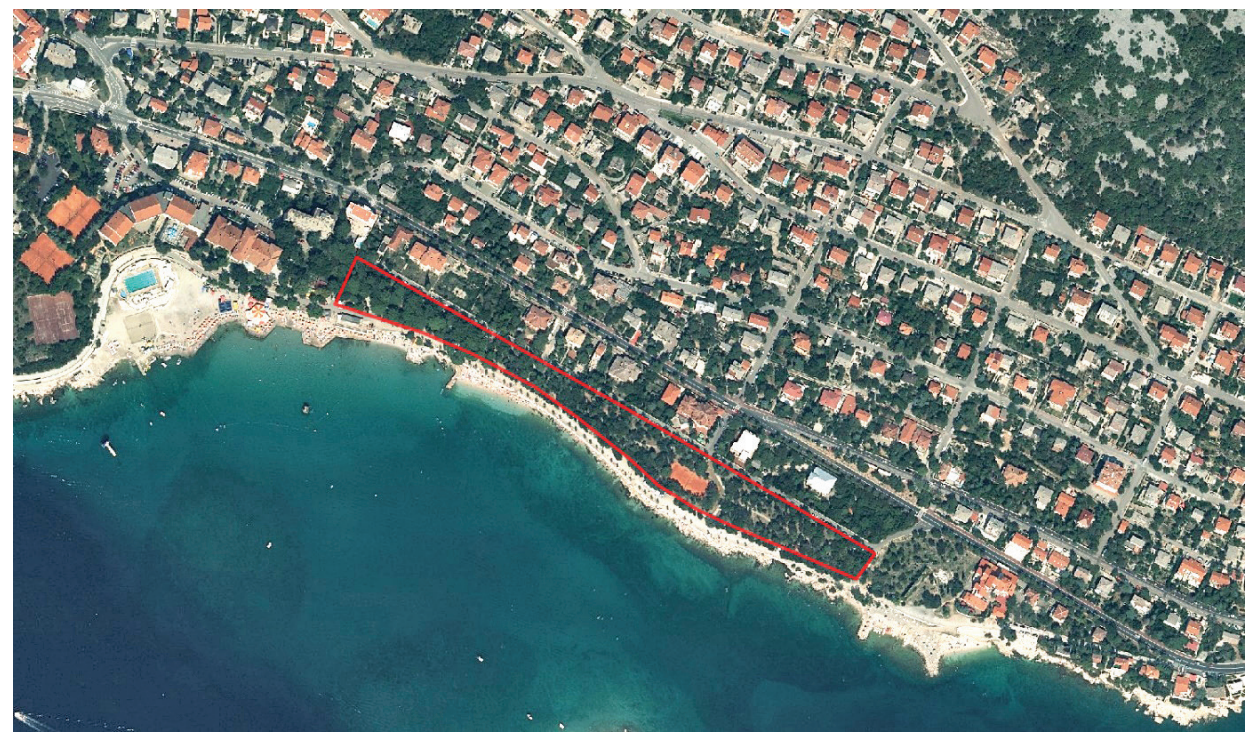

Slika 2. Granica obuhvata označena crvenom bojom

Figure 2 Research area marked in red

Zbog točnijeg određivanja lokacije svake vrste, ali i mogućnosti kasnije provjere, korištena je podjela parka na 38 polja (Ćustić, 2004.). Redni brojevi polja formirani su od najmanjeg na lijevoj do najvećeg na desnoj strani slike. Prvo polje nalazi se na sjeverozapadnoj, a zadnje na jugoistočnoj strani parka (Slika 3).

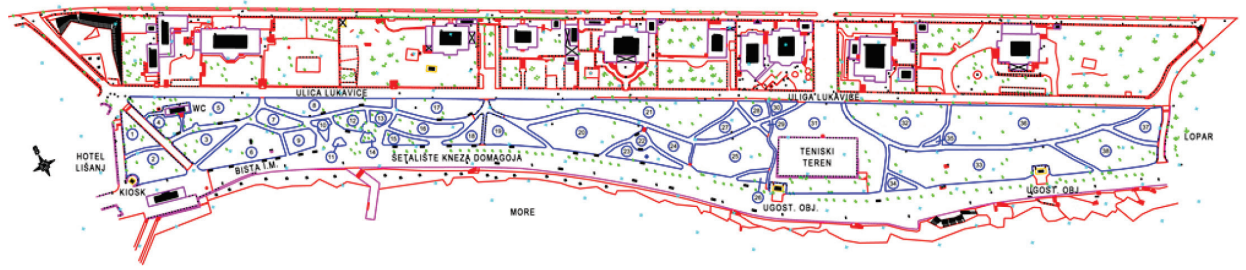

Slika 3. Podjela parka na polja koja su označena plavom bojom (Ćustić, 2004.; obrada Boris Pecigoš, 2015.)

Figure 3 Division of the park into fields marked in blue color 
Za determinaciju biljnih vrsta korišteni su uobičajeni ključevi i ikonografije: Javorka i Csapody (1934.), Bonnier (1962.), Tutin i sur. (1964. - 1980., 1993.), Pigniatti (1982.), Domac (1994.), Vidaković i Franjić (2004.).

Porodice i biljne vrste navedeni su u popisu flore abecednim redom, a imena svojti usklađena prema Nikoliću (2018.). Za svaku biljnu vrstu navodi se životni oblik, florni element i broj zabilježenih jedinki.

Životni oblici određeni su prema Garckeu (1972.) i Pigniattiju (1982.), a nadopunjeni podacima o lokalnoj flori prema Kovačeviću (1976.). Za životne oblike korištene su sljedeće kratice:

P Fanerofiti

NP Nanofanerofiti

Fitogeografska analiza (florni elementi) napravljena je prema Garckeu (1972.) i Nikoliću (2018.). Za florne elemente korištene su sljedeće kratice:

$\begin{array}{ll}\text { euras } & \text { euroazijski florni element } \\ \text { eur } & \text { europski florni element } \\ \text { med } & \text { mediteranski florni element } \\ \text { submed } & \text { submediteranski florni element } \\ \text { subatl } & \text { subatlantski florni element } \\ \text { adv } & \text { adventivne vrste koje su prema porijeklu označene: }\end{array}$

Sj. Am. (Sjeverna Amerika), Az. (Azija), Af. (Afrika)

kult kultivirane vrste

\section{REZULTATI I RASPRAVA}

Istraživanjem je obuhvaćeno ukupno 67 drvenastih vrsta koje su raspoređene u 33 porodice (Tablica 1 ). 
M. Poje i sur.: Dendoflora parka Ivana Mažuranića u Novom Vinodolskom

Tablica 1. Popis dendroflore u parku Ivana Mažuranića u Novom Vinodolskom (ŽO životni oblik, FE - florni element, UB - ukupan broj)

Table 1 List of woody plants in Ivan Mazuranic park in Novi Vinodolski (ŽO - life form, FE - floral element, UB - total number)

\begin{tabular}{|c|c|c|c|c|c|}
\hline $\begin{array}{l}\text { Porodica } \\
\text { Family }\end{array}$ & $\begin{array}{l}\text { Znanstveni naziv } \\
\text { Taxon name }\end{array}$ & $\begin{array}{l}\text { Narodni naziv } \\
\text { Common name }\end{array}$ & $\mathrm{ŽO}$ & $\mathrm{FE}$ & UB \\
\hline Aceraceae & Acer monspessulanum L. & maklen & $\mathrm{P}$ & subatl & 80 \\
\hline \multirow{2}{*}{ Agavaceae } & Yucca aloifolia $\mathrm{L}$. & divovska juka & $\mathrm{P}$ & $\operatorname{adv}(\mathrm{Sj} . \mathrm{Am})$. & 4 \\
\hline & Yucca gloriosa L. & krasolika juka & $\mathrm{P}$ & $\operatorname{adv}(\mathrm{Sj} . \mathrm{Am})$. & 3 \\
\hline Anacardiaceae & Pistacia terebinthus L. & smrdljika & $\mathrm{P}$ & med & 61 \\
\hline Apocynaceae & $\begin{array}{l}\text { Trachelospermum } \\
\text { jasminoides (Lindl.) Lem. }\end{array}$ & zvjezdasti jasmin & $\mathrm{P}$ & adv (Az.) & 4 \\
\hline \multirow[b]{2}{*}{ Aracaceae } & Trachycarpus excelsa & visoka žumara & $\mathrm{P}$ & $\operatorname{adv}($ Az.) & 2 \\
\hline & $\begin{array}{l}\text { Trachycarpus fortunei } \\
\text { (Hook.) H.Wendl. }\end{array}$ & niska žumara & $\mathrm{P}$ & $\operatorname{adv}(\mathrm{Az})$. & 1 \\
\hline \multirow{4}{*}{ Araliaceae } & $\begin{array}{l}\text { Hedera colchica }(\text { K.Koch) } \\
\text { K.Koch }\end{array}$ & kavkaski bršljan & $\mathrm{P}$ & euras & 3 \\
\hline & $\begin{array}{l}\text { Hedera colchica }(\text { K.Koch) } \\
\text { K.Koch 'Dentata variegata' }\end{array}$ & perzijski bršljan & $\mathrm{P}$ & kult & 840 \\
\hline & $\begin{array}{l}\text { Hedera colchica (K.Koch) } \\
\text { K.Koch 'Sulphur Heart' } \\
\end{array}$ & $\begin{array}{l}\text { bršljan velikolisni } \\
\text { žuto panaširanog lista }\end{array}$ & $\mathrm{P}$ & kult & 300 \\
\hline & Hedera helix L. & bršljan & $\mathrm{P}$ & euras & 33 \\
\hline Berberidaceae & Nandina domestica Thunb. & nandina & $\mathrm{P}$ & $\operatorname{adv}(\mathrm{Az})$. & 10 \\
\hline Buxaceae & Buxus sempervirens L. & šimšir & NP & subatl & 1 \\
\hline Caesalpiniaceae & Gleditsia triacanthos L. & trnovac & $\mathrm{P}$ & $\operatorname{adv}(\mathrm{Sj} . \mathrm{Am})$. & 1 \\
\hline Caprifoliaceae & Viburnum tinus L. & lemprika & $\mathrm{P}$ & med & 68 \\
\hline \multirow{2}{*}{ Celastraceae } & Euonymus europaeus L. & obična kurika & NP & euras & 1 \\
\hline & Euonymus japonica Thunb. & japanska kurika & NP & $\operatorname{adv}(\mathrm{Az})$. & 1 \\
\hline Cistaceae & Cistus $\times$ purpureus Lam. & bušin & NP & kult & 8 \\
\hline \multirow{4}{*}{ Cupressaceae } & Cupressus arizonica Greene & čempres arizonski & $\mathrm{P}$ & $\operatorname{adv}(\mathrm{Am})$. & 1 \\
\hline & $\begin{array}{l}\text { Cupressus horizontalis } \\
\text { Mill. }\end{array}$ & $\begin{array}{l}\text { vazdazeleni čempres } \\
\text { horizontalne krošnje }\end{array}$ & $\mathrm{P}$ & med & 46 \\
\hline & Cupressus sempervirens L. & zimzeleni čempres & $\mathrm{P}$ & med & 17 \\
\hline & Juniperus oxycedrus L. & šmrika, smrić & $\mathrm{P}$ & euras & 11 \\
\hline \multirow{6}{*}{ Fabaceae } & Cercis siliquastrum L. & judić & $\mathrm{P}$ & med & 10 \\
\hline & Colutea arborescens L. & drvolika pucalina & NP & submed & 14 \\
\hline & $\begin{array}{l}\text { Coronilla emerus L. ssp. } \\
\text { emeroides Boiss. et Spruner }\end{array}$ & grmoliki grašar & NP & submed & 12 \\
\hline & $\begin{array}{l}\text { Laburnum anagyroides } \\
\text { Medik. }\end{array}$ & obični zanovijet & $\mathrm{P}$ & submed & 9 \\
\hline & Robinia pseudoacacia L. & bagrem & $\mathrm{P}$ & $\operatorname{adv}(\mathrm{Sj} . \mathrm{Am})$. & 5 \\
\hline & Sophora japonica L. & japanska sofora & NP & $\operatorname{adv}(\mathrm{Az})$. & 7 \\
\hline \multirow{2}{*}{ Fagaceae } & Quercus ilex L. & crnika, česmina & $\mathrm{P}$ & med & 106 \\
\hline & Quercus pubescens Willd. & hrast medunac & $\mathrm{P}$ & subatl & 2 \\
\hline
\end{tabular}


M. Poje i sur.: Dendoflora parka Ivana Mažuranića u Novom Vinodolskom

\begin{tabular}{|c|c|c|c|c|c|}
\hline \multirow[b]{2}{*}{ Labiatae } & Rosmarinus officinalis L. & ružmarin & NP & med & 33 \\
\hline & $\begin{array}{l}\text { Rosmarinus officinalis } \\
\text { 'Prostratus' }\end{array}$ & ružmarin puzajući & NP & med & 10 \\
\hline Lauraceae & Laurus nobilis L. & lovor & $\mathrm{P}$ & med & 346 \\
\hline Magnoliaceae & $\begin{array}{l}\text { Magnolia grandiflora } \\
\text { 'Galisoniensis' }\end{array}$ & magnolija velecvjetna & $\mathrm{P}$ & $\operatorname{adv}(\mathrm{Sj} . \mathrm{Am})$. & 2 \\
\hline Myrtaceae & Myrtus communis L. & obična mirta & NP & med & 4 \\
\hline \multirow{7}{*}{ Oleaceae } & Fraxinus ornus L. & crni jasen & $\mathrm{P}$ & med & 89 \\
\hline & Jasminum mesnyi Hance. & zimski jasmin & $\mathrm{P}$ & $\operatorname{adv}(\mathrm{Az})$. & 3 \\
\hline & $\begin{array}{l}\text { Ligustrum japonicum } \\
\text { Thunb. }\end{array}$ & japanska kalina & $\mathrm{P}$ & adv (Az.) & 12 \\
\hline & $\begin{array}{l}\text { Ligustrum ovalifolium } \\
\text { Hassk. }\end{array}$ & kalina & $\mathrm{P}$ & adv (Az.) & 41 \\
\hline & Olea europaea L. & maslina & $\mathrm{P}$ & euras & 144 \\
\hline & Phillyrea latifolia L. & širokolisna komorika & $\mathrm{P}$ & med & 1 \\
\hline & Syringa vulgaris L. & jorgovan & $\mathrm{P}$ & eur & 77 \\
\hline \multirow{6}{*}{ Pinaceae } & $\begin{array}{l}\text { Cedrus atlantica (Endl.) } \\
\text { Carriere }\end{array}$ & atlantski cedar & $\mathrm{P}$ & $\operatorname{adv}($ Af.) & 2 \\
\hline & $\begin{array}{l}\text { Cedrus deodara (D. Don) } \\
\text { G. Don }\end{array}$ & indijski cedar & $\mathrm{P}$ & $\operatorname{adv}($ Az.) & 6 \\
\hline & Pinus brutia Ten. & bor brucijski & $\mathrm{P}$ & med & 53 \\
\hline & Pinus halepensis Mill. & bijeli bor & $\mathrm{P}$ & med & 12 \\
\hline & $\begin{array}{l}\text { Pinus nigra J. F. Arnold } \\
\text { ssp. nigra }\end{array}$ & bor crni & $\mathrm{P}$ & euras & 36 \\
\hline & Pinus pinea $\mathrm{L}$. & pinija & $\mathrm{P}$ & med & 4 \\
\hline \multirow{2}{*}{ Pittosporaceae } & $\begin{array}{l}\text { Pittosporum tobira } \\
\text { (Thunb.) Aiton }\end{array}$ & pitospor & $\mathrm{P}$ & $\operatorname{adv}(\mathrm{Az})$. & 32 \\
\hline & $\begin{array}{l}\text { Pittosporum tenuifolium } \\
\text { Gaertn. }\end{array}$ & tobirovac, pitosora & $\mathrm{P}$ & adv (Az.) & 7 \\
\hline Punicaceae & Punica granatum $\mathrm{L}$. & nar, šipak & $\mathrm{P}$ & med & 2 \\
\hline \multirow{5}{*}{ Rosaceae } & $\begin{array}{l}\text { Cotoneaster dammeri } \\
\text { 'Radicans' }\end{array}$ & puzava dunjarica & $\mathrm{P}$ & $\operatorname{adv}(\mathrm{Az})$. & 1 \\
\hline & \begin{tabular}{|l|}
$\begin{array}{l}\text { Cotonester salicifolius } \\
\text { 'Parkteppich' }\end{array}$ \\
\end{tabular} & $\begin{array}{c}\text { vrbolisna puzava } \\
\text { dunjarica }\end{array}$ & $\mathrm{P}$ & $\operatorname{adv}(\mathrm{Az})$. & 14 \\
\hline & $\begin{array}{l}\text { Prunus cerasifera Ehrh. } \\
\text { 'Atropurpurea' ili var. } \\
\text { atropurpurea } \text { H. Jaeger }\end{array}$ & $\begin{array}{c}\text { šljiva crvenolisna } \\
\text { ukrasna }\end{array}$ & $\mathrm{P}$ & euras & 1 \\
\hline & Prunus mahaleb L. & rašeljka & $\mathrm{P}$ & submed & 4 \\
\hline & $\begin{array}{l}\text { Spirea } \mathrm{x} \text { vanhouttei (Briot) } \\
\text { Zabel }\end{array}$ & suručica & $\mathrm{P}$ & kult & 7 \\
\hline \multirow{2}{*}{ Ruscaceae } & Ruscus aculeatus L. & bodljikava veprina & NP & euras & 9 \\
\hline & Ruscus hypoglossum L. & mekolisna veprina & NP & euras & 18 \\
\hline Santalaceae & Osyris alba L. & bijela metla & NP & med & 9 \\
\hline Sapindaceae & $\begin{array}{l}\text { Koelreuteria paniculata } \\
\text { Laxm. }\end{array}$ & kelreuterija & $\mathrm{P}$ & $\operatorname{adv}(\mathrm{Az})$. & 1 \\
\hline
\end{tabular}


M. Poje i sur.: Dendoflora parka Ivana Mažuranića u Novom Vinodolskom

\begin{tabular}{|l|l|c|c|c|c|}
\hline \multirow{2}{*}{ Simaroubaceae } & $\begin{array}{l}\text { Ailanthus altissima } \text { (Mill.) } \\
\text { Swingle }\end{array}$ & žljezdasti pajasen & $\mathrm{P}$ & adv (Az.) & 38 \\
\hline Smilicaceae & Smilax aspera L. & crvena tetivika & NP & med & 33 \\
\hline Taxaceae & Taxus baccata L. & tisa & P & subatl & 3 \\
\hline \multirow{2}{*}{ Tiliaceae } & Tilia platyhyllos Scop. & lipa krupnolisna & P & subatl & 3 \\
\cline { 2 - 6 } & Tilia cordata Mill. & sitnolisna lipa & P & adv (Az.) & 1 \\
\hline \multirow{2}{*}{ Ulmaceae } & Celtis australis L. & južnjački koprivić & P & euras & 23 \\
\cline { 2 - 6 } & Ulmus minor Mill. & plutasti poljski brijest & P & subatl & 11 \\
\hline
\end{tabular}

Taksonomskom analizom utvrđeno je 67 vrsta koje su raspoređene u 32 porodice. Četiri porodice (s jedanaest vrsta) pripadaju golosjemenjačama, dok ostalih 28 porodica (56 vrsta) pripada kritosjemenjačama (Tablica 2). Razredu Magnoliopsida (dvosupnice) pripada svih 28 porodica.

Tablica 2. Taksonomska analiza parkovne dendroflore

Table 2 Taksonomic analysis of park dendroflora

\begin{tabular}{|l|c|c|c|}
\hline \multicolumn{1}{|c|}{ Taksoni -Taxa } & Gymnospermae & Angiospermae & Ukupno - Total \\
\hline Porodice -Families & 4 & 28 & 32 \\
\hline Vrste - Species & 11 & 56 & 67 \\
\hline Udio vrsta & $16,42 \%$ & $83,58 \%$ & $100,00 \%$ \\
\hline
\end{tabular}

Prema broju biljnih vrsta, najzastupljenije su sljedeće porodice: Oleaceae (7 vrsta), Pinaceae (6 vrsta), Fabaceae (6 vrsta) i Rosaceae (5 vrsta). Čak 17 porodica zastupljeno je samo s jednom vrstom (Grafikon 1). Ovakav raspored ukazuje na veliku raznolikost dendrološkog materijala koji je korišten pri uređenju parka, ali i cjelokupne flore istraživanog područja.

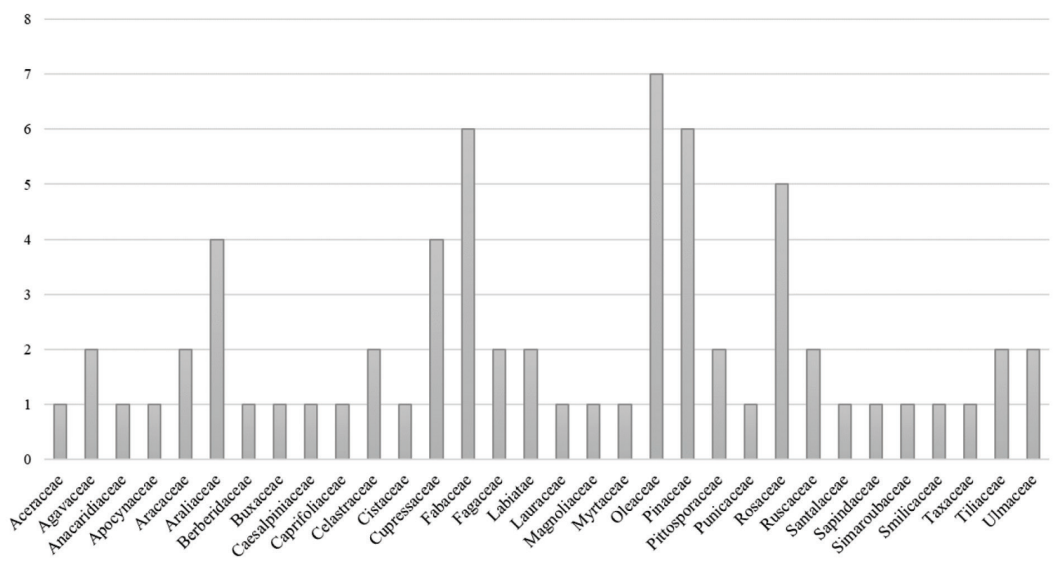

Grafikon 1. Zastupljenost vrsta prema porodicama Graph 1 Representation of species by families 
S obzirom da je istraživana dendroflora parka zabilježena su samo dva životna oblika $\mathrm{i}$ to najviše fanerofita (53 vrsta; $79,10 \%$ ), te nanofanerofita (14 vrsta; 20,90\%).

Fitogeografskom analizom utvrđeno je da su vrste raspoređene unutar sedam flornih elemenata. Najviše biljnih vrsta, njih 24, pripada adventivnim vrstama različitog porijekla, zatim slijede vrste koje pripadaju mediteranskom flornom elementu (18 vrsta) te biljne vrste koje pripadaju euroazijskom flornom elementu (10 biljnih vrsta) (Slika 4).

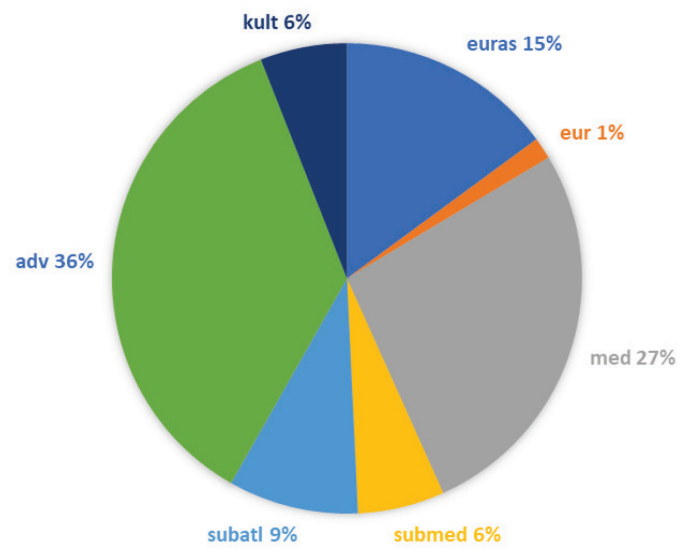

Slika 4. Zastupljenost vrsta prema flornom elementu

Figure 4 Representation of species according to the floral element

Iako su adventivne vrste različitog porijekla najbrojnije $\mathrm{u}$ odnosu na ostale biljne vrste, većina flore autohtonog je karaktera. Po brojnosti, valja izdvojiti maslinu (144 zabilježenih primjeraka), crniku (106 primjeraka), crni jasen (89 primjeraka) i smrdljiku (61 primjerak) te lovor (346 primjeraka) i lempriku (68 primjeraka). Autohtone vrste izuzetno su važne za očuvanje izvornih i naslijeđenih krajobraznih obilježja odnosno samog identiteta prostora (Šišić, 2011.).

Tijekom povijesti, zbog raznih razloga (neadekvatno održavanje, bolesti i dr.) nestale su brojne biljne vrste koje su nekad krasile park, a zabilježene su na fotografijama. Tako su nestale agave, australske kordiline (Cordyline australis (Forst. f.) Hook. f.), arizonski čempresi (Cupressus arizonica Greene), europski ariši (Larix decidua Mill.) i dr. To je donekle razumljivo budući da se slični procesi događaju i u drugim parkovima (Obad Šćitaroci i Bojanić-Obad Šćitaroci, 1996.). 
M. Poje i sur.: Dendoflora parka Ivana Mažuranića u Novom Vinodolskom

\section{ZAKLJUČAK}

Istraživanjem provedenim $\mathrm{u}$ parku Ivana Mažuranića $\mathrm{u}$ Novom Vinodolskom u vegetacijskim sezonama 2014. i 2016. godine zabilježeno je ukupno 67 biljnih svojti. Biljne vrste raspoređene su unutar 32 porodice od kojih prema brojnosti vrsta prednjače Oleaceae, Fabaceae, Pinaceae i Rosaceae. Također, valja napomenuti kako je 17 porodica zastupljeno samo s jednom vrstom.

Fitogeografskom analizom utvrđeno je da su vrste raspoređene unutar sedam flornih elemenata. Najviše vrsta, njih 24 , pripada adventivnim vrstama, zatim slijede vrste koje pripadaju mediteranskom flornom elementu (18 vrsta) te biljne vrste koje pripadaju euroazijskom flornom elementu (10 biljnih vrsta).

Što se tiče životnog oblika ustanovljeno je najviše fanerofita (52 biljnih vrsta) što čini udio od $79,10 \%$.

Općenito, stanje dendroflore je zadovoljavajuće iako je tijekom posljednjeg desetljeća zabilježeno smanjenje biljnog fonda pa je potrebno posvetiti više pažnje održavanju i njezi. To se osobito odnosi na stabla jer ima dosta oštećenih i neadekvatno orezanih primjeraka. Pri bilo kakvoj budućoj revitalizaciji, važno je zadržati sva izvorna krajobrazna obilježja parka.

\section{LITERATURA}

1. Adkins, R.V.C., M.R. Kuhns, D.J. Blahna, and M.W. Blood (1997.): Urban forest resource management at Hill Air Force Base, Ogden, Utah. Journal of Arboriculture 23(4):136-143.

2. Babić, D. (ur.) (1995.): Temeljna literatura i Kronologija o Novom Vinodolskom. Gradsko poglavarstvo, Novi Vinodolski.

3. Blažević, B. (2014.): Prilog istraživanju hotelijerstva na području Crikveničkovinodolske rivijere. Vinodolski zbornik 15: 39-86

4. Bonnier G. (1962.): Flore comléete illustrée en Couleurs de France, Suisse et Belgique, 1-12. Neuchatel et Bruxelles, Paris.

5. Brozović, B. (ur.) (1938.): Vinodolska knežija i morska kupališta. Zaklada tiskare Narodnih novina, Zagreb.

6. Ćustić S. (2004.): Projekt obnove Parka "Ivan Mažuranić" Novi Vinodolski. "Fontana" uređenje i uzdržavanje zelenih površina, Zagreb Obrada: Boris Pecigoš, 2015. 
M. Poje i sur.: Dendoflora parka Ivana Mažuranića u Novom Vinodolskom

7. Domac R. (1994.): Flora Hrvatske: priručnik za određivanje bilja. Školska knjiga, Zagreb.

8. Garcke A. (1972.): Illustrierte Flora Deutschland und angrenzende gebiete, geffasskryptogamen und Blutenpflanzen. Berlin - Hamburg.

9. Izvješće o stanju u prostoru Grada Novi Vinodolski za razdoblje od 2007. do 2014. godine (2014.): Službene novine Primorsko-goranske županije 41/14

10. Javorka S., Csapody V. (1934.): A magyar flóra Képekben (Iconographia Florae Hungaricae). "Studium", Budapest.

11. Jemrić, D. (2018.): Inventarizacija trajnica u parku Ivana Mažuranića u Novom Vinodolskom. Završni rad, Sveučilište u Zagrebu Agronomski fakultet.

12. Ježić, M. (1963.): Razvoj turizma u Novom Vinodolskom. Vlastita naklada, Novi Vinodolski.

13. Kabalin, S. (1985.): Novi Vinodolski - prvo stoljeće turizma. Turistička zajednica Novi Vinodolski, Novi Vinodolski.

14. Kabalin, S. (1995.): Fotomonografija Novi Vinodolski. Tipograf, Rijeka.

15. Martin, N.A., A.H. Chappelka, G.J. Keever, and E.F. Loewenstein (2011.): A $100 \%$ tree inventory using i-tree eco protocol: A casestudy at Auburn University, Alabama, U.S. Arboriculture \& Urban Forestry 37(5):207-212.

16. McBride, J.R., Nowak, D.J. (1989.): Urban park tree inventora. Arboricultural journal 13: $345-361$.

17. Nielsen A.B., Östberg J., Delshammar T. (2014.): Review of Urban Tree Inventory Methods Used to Collect Data at Single-Tree Level. Arboriculture \& Urban Forestry 40(2): 96-111

18. Nikolić T. (ed.), (2018.): Flora Croatica baza podataka / Flora Croatica Database. On-Line URL: http://hirc.botanic.hr/fcd. Botanički zavod s Botaničkim vrtom, Prirodoslovno-matematički fakultet, Sveučilište u Zagrebu.

19. Obad Šćitaroci M., Bojanić-Obad Šćitaroci, B. (1996.): Gradski park u Virovitici. Prostor 4(2(12)): 157-174

20. Odluka o određivanju imena šetnice, ulice i parka na području Grada Novog Vinodolskog (2015.): Službene novine Primorsko-goranske županije 27/15

21. Pigniatti, S. (1982.): Flora D'Italia 1-3. Edagricole, Bologna.

22. Seferagić, D. (2010.): Usponi i padovi Novog Vinodolskog (Proturječja glokalnog razvoja - studija slučaja) Sociologija i prostor 48(2(187)): 223-246

23. Strategija razvoja Grada Novog Vinodolskog za razdoblje od 2015. do 2020. godine (2015.) iDEO PLAN, Pula.

24. Studio Perivoj d.o.o. (2005.): Projekt s planom uređenja (revizija projekta obnove parka). Studio Perivoj d.o.o., Malinska. 
25. Šegota T., Filipčić A. (2003.): Köppenova podjela klima i hrvatsko nazivlje, Geoadria 8(1): 17-37.

26. Šišić, B. (2011.): Autohtono zelenilo - čimbenik mjesnog identiteta u dubrovačkom kraju. Klesarstvo i graditeljstvo XXII (1-2): 71-89

27. Tutin T. G., Heywood V. H. (eds.) (1964 - 1980., 1993.): Flora Europaea, 1-5. University Press, Cambridge.

28. Urbanistički plan uređenja naselja Novi Vinodolski (2017.)

29. Vidaković M., Franjić J. (2004.): Golosjemenjače. Šumarski fakultet, Zagreb.

Adrese autora - Author's addresses:

Miroslav Poje, e-mail: poje@agr.hr

Dario Jemrić;

Dubravka Dujmović-Purgar;

Ines Han Dovedan;

Agronomski fakultet, Sveučilišta u Zagrebu

Svetošimunska cesta 25, 10000 Zagreb, Croatia
Primljeno - received:

14.01.2019. 